\title{
Activities of the peptidyl transferase center of ribosomes lacking protein $\mathrm{L27}$
}

\author{
CRISTINA MARACCI, INGO WOHLGEMUTH, and MARINA V. RODNINA \\ Department of Physical Biochemistry, Max Planck Institute for Biophysical Chemistry, 37077 Goettingen, Germany
}

\begin{abstract}
The ribosome is the molecular machine responsible for protein synthesis in all living organisms. Its catalytic core, the peptidyl transferase center (PTC), is built of rRNA, although several proteins reach close to the inner rRNA shell. In the Escherichia coli ribosome, the flexible N-terminal tail of the ribosomal protein L27 contacts the A- and P-site tRNA. Based on computer simulations of the PTC and on previous biochemical evidence, the N-terminal $\alpha$-amino group of L27 was suggested to take part in the peptidyl-transfer reaction. However, the contribution of this group to catalysis has not been tested experimentally. Here we investigate the role of L27 in peptide-bond formation using fast kinetics approaches. We show that the rate of peptide-bond formation at physiological $\mathrm{pH}$, both with aminoacyl-tRNA or with the substrate analog puromycin, is independent of the presence of L27; furthermore, translation of natural mRNAs is only marginally affected in the absence of L27. The $\mathrm{pH}$ dependence of the puromycin reaction is unaltered in the absence of L27, indicating that the $\mathrm{N}$-terminal $\alpha$-amine is not the ionizing group taking part in catalysis. Likewise, L27 is not required for the peptidyl-tRNA hydrolysis during termination. Thus, apart from the known effect on subunit association, which most likely explains the phenotype of the deletion strains, L27 does not appear to be a key player in the core mechanism of peptide-bond formation on the ribosome.
\end{abstract}

Keywords: ribosome; translation; peptide-bond formation; tRNA; ribozyme

\section{INTRODUCTION}

In all living organisms, the ribosome catalyzes the sequential polymerization of amino acids into functional proteins. In each round of translation elongation, the ribosome selects an aminoacyl-tRNA (aa-tRNA) corresponding to the mRNA codon presented in the A site. After accommodation of the $3^{\prime}$ end of the A-site tRNA in the peptidyl transferase center (PTC) of the ribosome, the amino group of the aa-tRNA nucleophillically attacks the ester of the peptidyl-tRNA in the $\mathrm{P}$ site leading to the formation of a peptide bond and the transfer of the peptidyl chain onto the A-site tRNA. The PTC resides in the large subunit of the ribosome (50S in bacteria) and is constituted mainly by rRNA, which is thought to be responsible for the catalytic activity. However, crystal structures of the Thermus thermophilus ribosome in complex with tRNAs (Selmer et al. 2006; Voorhees et al. 2009) showed that protein L27, which is conserved in prokaryotes, extends far enough into the PTC to potentially contribute to catalysis. L27 is a small protein located at the base of the central protuberance of the $50 \mathrm{~S}$ subunit. Its long, conserved N-terminal tail protrudes into the PTC, where it was

\footnotetext{
Corresponding author: rodnina@mpibpc.mpg.de

Article published online ahead of print. Article and publication date are at http://www.rnajournal.org/cgi/doi/10.1261/rna.053330.115. Freely available online through the RNA Open Access option.
}

reported to interact with both A-site and P-site tRNAs (Wower et al. 2000; Maguire et al. 2005; Voorhees et al. 2009; Jenner et al. 2010).

Peptide-bond formation on the ribosome is for most aa-tRNAs rate-limited by their accommodation into the A site (Pape et al. 1998; Wohlgemuth et al. 2010; Johansson et al. 2011). Therefore, pre-steady state kinetic studies that aimed at determining the reaction mechanism often utilized aa-tRNA analogs, such as puromycin (Pmn) or its derivatives (e.g., C-Pmn [Katunin et al. 2002; Okuda et al. 2005; Brunelle et al. 2006; Wohlgemuth et al. 2006; Beringer and Rodnina 2007]). When Pmn is used as substrate, the peptidyl-transfer (PT) reaction shows a pronounced $\mathrm{pH}$ dependence with two ionizing groups, indicating that besides the amino group of the substrate (6.9 for Pmn [Katunin et al. 2002]), another ionizing group, with a $\mathrm{pKa}$ of $\sim 7.5$, contributes to catalysis (Katunin et al. 2002; Beringer and Rodnina 2007). Based on computer simulations of the pre- and post-PT state of the ribosome, this group has been proposed to be the N-terminal amine of L27 (Trobro and Åqvist 2008; Xiao and Wang 2012). The absence of $\mathrm{L} 27$ is thus predicted to alter the $\mathrm{pH}$ dependence of PT; however, the contribution of this

(C) 2015 Maracci et al. This article, published in RNA, is available under a Creative Commons License (Attribution 4.0 International), as described at http://creativecommons.org/licenses/by/4.0/. 
ionizable group to the PT reaction has not been experimentally tested so far.

Early biochemical data indicated a functional role for L27 in the PT activity. Escherichia coli strains in which L27 was deleted grew six times slower than the wild type (wt), and ribosomes lacking L27 were found to carry sub-stoichiometric amounts of L16, L21, and L20. The PT activity of $\Delta \mathrm{L} 27$ ribosomes was slightly reduced, both in the presence of Pmn or native A-site substrate (Phe-tRNA ${ }^{\text {Phe }}$ ) (Wower et al. 1998). Truncation of the $\mathrm{N}$-terminal tail of $\mathrm{L} 27$ revealed that the absence of as few as the first three residues reduces the PT activity to the level of $\Delta \mathrm{L} 27$ ribosomes (Maguire et al. 2005). smFRET data indicated that the main function of L27 might be to stabilize the tRNAs on the ribosome (Wang and Xiao 2012; Xiao and Wang 2012), which for some amino acids may contribute to the acceleration of the PT reaction. Furthermore, the $\alpha$-amino group of L27 was recently suggested to take part in proton transfer during the PT reaction, assisting the $5^{\prime}$-phosphate oxygen of the A-site A76 in the deprotonation of the nucleophile in the transition state (Polikanov et al. 2014). Although L27 is not present in Archaea and Eukaryotes, another ribosomal protein, the archaeal L10e and its eukaryotic homolog RPL10, extends a loop in the same position as the L27 tail (Armache et al. 2010); mutations in this conserved loop are lethal (Hofer et al. 2007). Validation of the role of L27 in the PT reaction for all or perhaps only certain incoming amino acids would, however, require detailed biochemical and kinetic studies. Here we use rapid kinetics methods to precisely quantify the contribution of L27 on the activity of the PTC.

\section{RESULTS AND DISCUSSION}

We purified ribosomes from the E. coli strain lacking the gene rpmA encoding L27 (IW312 strain; hereafter referred to as $\Delta \mathrm{L} 27)$ and from the same strain expressing $\mathrm{L} 27$ from a plasmid (IW312+ pPOTA1:rpmA; hereafter referred to as wt). Ribosome profiles obtained by sucrose-gradient centrifugation showed the absence of a pronounced $70 \mathrm{~S}$ peak in the $\Delta \mathrm{L} 27$ strain, indicating that most ribosomes are dissociated into the subunits at $5 \mathrm{mM} \mathrm{Mg}^{2+}$ (Fig. 1A). In accordance with earlier results of sucrose-gradient analysis (Wower et al. 1998), impaired subunit association might explain the slow growth phenotype of this strain. We thus collected fractions containing a mixture of $50 \mathrm{~S}$ and $70 \mathrm{~S}$ and confirmed the absence of L27 by quantitative mass spectrometry (Fig. 1B) and Western blotting (Fig. 1C). The active ribosome concentration was determined by preparing $70 \mathrm{~S}$ initiation complexes in the presence of mRNA, initiation factors, and increasing concentration of $\left.\mathrm{f}^{3} \mathrm{H}\right] \mathrm{Met}^{\mathrm{tRNA}}{ }^{\mathrm{fMet}}$ (Fig. 1D). More than $90 \%$ of the wt ribosomes formed stable complexes with $\mathrm{fMet} \mathrm{tRNA}{ }^{\mathrm{fMet}}$, whereas $\Delta \mathrm{L} 27$ ribosomes initiated to only $\sim 40 \%$, indicating that the preparation contains significant portion of free $50 \mathrm{~S}$ subunits and/or incomplete and inactive $70 \mathrm{~S}$ ribosomes.
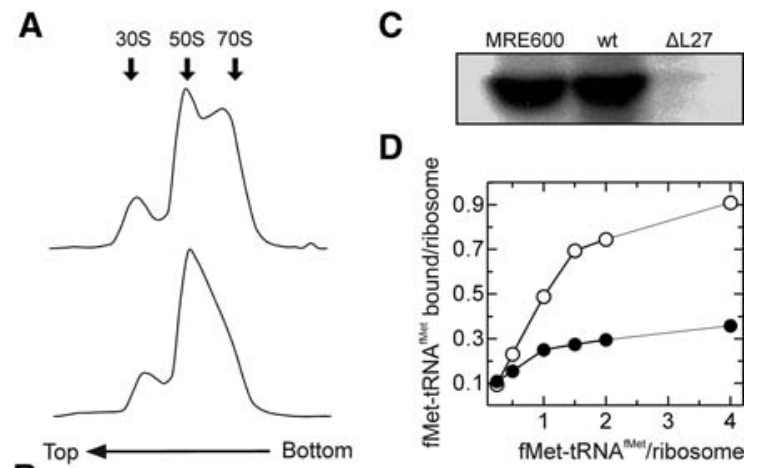

$$
\text { B }
$$

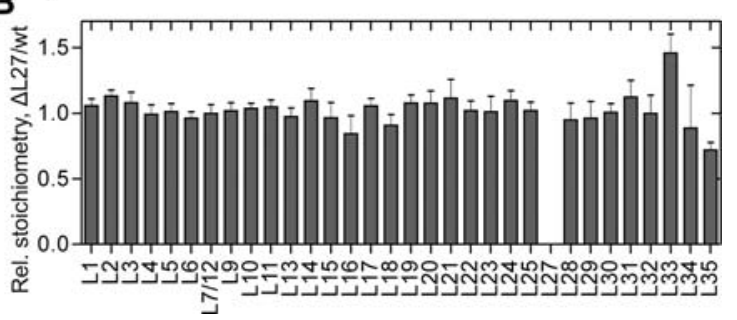

FIGURE 1. Characterization of $\Delta$ L27 ribosomes. (A) Sucrose-gradient centrifugation profile of wt (upper panel) and $\Delta \mathrm{L} 27$ (bottom panel) ribosomes at $5 \mathrm{mM} \mathrm{Mg}^{2+}$. (B) Quantification of ribosomal proteins by mass spectrometry. The ratio of the average protein concentrations (as defined by label-free quantification) $\Delta \mathrm{L} 27 /$ wt was plotted. Error bars represent the standard deviation of four technical replicates. $(C)$ Western blot of ribosomal proteins from MRE600, wt, and $\Delta \mathrm{L} 27$ ribosomes using anti-L27 antibody. $(D)$ Determination of the active concentration of $\Delta \mathrm{L} 27$ ribosomes. The extent of initiation was determined by the radioactivity retained on nitrocellulose filters after incubation of wt (open circles) or $\Delta \mathrm{L} 27$ (closed circles) ribosomes with mRNA, initiation factors, GTP, and increasing concentrations of $f\left[{ }^{3} \mathrm{H}\right]$ Met-tRNA $^{\mathrm{fMet}}$.

Previous reports indicated that in the presence of low concentrations of Pmn, formation of fMet-Pmn is impaired on ribosomes lacking L27 (Maguire et al. 2005). Because Pmn concentrations used in those experiments $(1 \mu \mathrm{M})$ were far below the $\mathrm{K}_{\mathrm{M}}$ value for the ribosome-Pmn complex $(\sim 1-30$ $\mathrm{mM}$, depending on the tRNA in the P site) (Youngman et al. 2004; Beringer et al. 2005; Wohlgemuth et al. 2008), the observed decrease in the kinetics of the Pmn reaction might be due to a Pmn binding defect, rather than the reduced PT rate. To distinguish between the $\mathrm{K}_{\mathrm{M}}$ and $\mathrm{k}_{\mathrm{cat}}$ effects, we first reproduced the previous studies using $\mathrm{fMet}-\mathrm{tRNA} \mathrm{fmet}^{\mathrm{fM}}$ and Pmn as P- and A-site substrates. Indeed, the extent of fMet-Pmn formation with $\Delta$ L27 ribosomes appeared lower compared to the wt (Fig. 2A); however, when the amount of active ribosomes was taken into account, it turned out that all ribosomes active in initiation were also active in the PT reaction (Fig. 2A). To verify this result, we repeated the experiment with initiation complexes (ICs) purified through a sucrose cushion; as determined by nitrocellulose filtration, $>50 \%$ of the IC formed with $\Delta \mathrm{L} 27$ ribosomes dissociated upon purification (not shown), indicating that binding of fMet-tRNA ${ }^{\text {fMet }}$ was somewhat weaker on the mutant ribosomes. The active concentration of the remaining stable complexes was calculated from the amount of $\left[{ }^{3} \mathrm{H}\right]$ Met-tRNA $^{\mathrm{fMet}}$ 

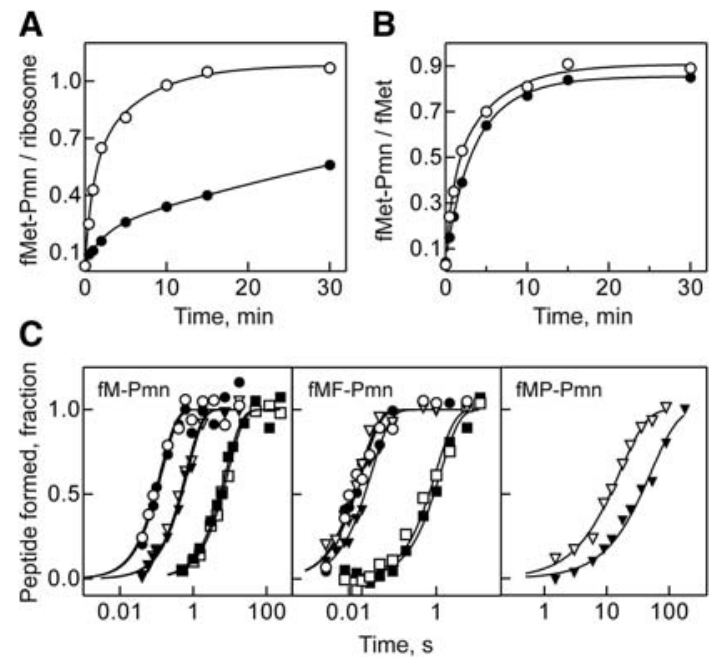

FIGURE 2. Peptide-bond formation with Pmn as A-site substrate. Unpurified $(A)$ or sucrose gradient-purified $(B)$ ICs prepared with wt (open circles) or $\Delta \mathrm{L} 27$ (closed circles) ribosomes $(0.25 \mu \mathrm{M})$ were mixed with Pmn $(1 \mu \mathrm{M})$, and the extent of dipeptide reaction was monitored over time. Solid lines represent the results of exponential fitting (see Materials and Methods). (C) Time courses of fMet-Pmn (left panel), fMetPhe-Pmn (middle panel), and fMetPro-Pmn (right panel) formation upon mixing of wt (open symbols) and $\Delta \mathrm{L} 27$ (closed symbols) IC $(50 \mathrm{nM})$ with high concentrations of Pmn $(2.5-10 \mathrm{mM})$ at $\mathrm{pH} 6.5$ (squares), 7.5 (triangles), and 8.5 (circles). Time courses were normalized for the extent of the reaction to facilitate visual inspection. Solid lines represent the results of exponential fitting of the time points. Rates of the fMet-Pmn reaction for wt and $\Delta \mathrm{L} 27$ ribosomes, respectively, were $0.11 \pm 0.1$ and $0.13 \pm 0.1 \mathrm{sec}^{-1}$ at $\mathrm{pH} 6.5 ; 1.6 \pm 0.1$ and $1.4 \pm 0.1$ $\mathrm{sec}^{-1}$ at $\mathrm{pH} 7.5$; and $7.8 \pm 1.7$ and $7.1 \pm 1.9 \mathrm{sec}^{-1}$ at $\mathrm{pH}$ 8.5. Rates of the fMetPhe-Pmn for wt and $\Delta \mathrm{L} 27$ ribosomes, respectively, were $1.0 \pm 0.2$ and $0.8 \pm 0.1 \mathrm{sec}^{-1}$ at $\mathrm{pH} 6.5 ; 55 \pm 6$ and $30 \pm 3 \mathrm{sec}^{-1}$ at $\mathrm{pH}$ 7.5; and $55 \pm 10$ and $49 \pm 10 \mathrm{sec}^{-1}$ at $\mathrm{pH}$ 8.5. Rates of the fMetPro-Pmn reaction at $\mathrm{pH} 7.5$ were $0.06 \pm 0.01$ and $0.02 \pm 0.01 \mathrm{sec}^{-1}$ for wt and $\Delta \mathrm{L} 27$ ribosome, respectively.

bound. These remaining ribosome complexes showed identical rates of peptide-bond formation (Fig. 2B), which shows that $\Delta \mathrm{L} 27$ ribosomes do not have a PT defect.

The ribosome group presumably involved in the PT reaction with Pmn has not been identified. If the $\mathrm{N}$-terminal a-amine of L27 takes part in catalysis, one would expect the $\mathrm{pH}$ dependence of the Pmn reaction to change in the absence of L27. To test this hypothesis, we compared the kinetics of fMet-Pmn formation at different $\mathrm{pH}$ values using $\Delta \mathrm{L} 27$ and wt ribosomes. This time, we determined the maximal rate of peptidebond formation at high concentrations of Pmn (Fig. 2C). As expected, the rate of fMet-Pmn formation depends on $\mathrm{pH}$. However, at a given $\mathrm{pH}$, the rates of the reaction were identical on the wt and $\Delta \mathrm{L} 27$ ribosomes. This finding indibosomes, respectively. cates that not only the PT activity at a defined $\mathrm{pH}$, but also the overall rate/pH profile is not altered in the absence of L27, which further strengthens the notion that the protein itself is completely dispensable for this reaction. A similar result was obtained when we followed the Pmn reaction on post-translocation complexes carrying an fMetPhe-tRNA ${ }^{\text {Phe }}$ in the $\mathrm{P}$ site at different $\mathrm{pH}$ values (Fig. 2C). Also in this case the rate of $\mathrm{fMetPhe}-\mathrm{Pmn}$ tripeptide formation was independent of the presence of L27. To check whether L27 might be more important for less reactive substrates such as proline (Wohlgemuth et al. 2008), which causes ribosomal stalling when more than two prolines have to be incorporated into the peptide (Doerfel et al. 2013; Ude et al. 2013), we checked the Pmn reaction with post-translocation complexes carrying a fMetPro-tRNA ${ }^{\text {Pro }}$ in the $\mathrm{P}$ site. In this case, the rate of peptide-bond formation was slightly decreased in the absence of L27 (0.02 $\mathrm{sec}^{-1}$, compared with the rate of $0.06 \mathrm{sec}^{-1} \mathrm{ob}-$ tained with wt ribosomes) (Fig. 2C).

Although L27 seems to be dispensable for PT with A-site tRNA analogs, it might still play a role in the presence of full-length aa-tRNAs. We thus determined the rate of fMetPhe formation in the absence of L27. ICs were mixed with saturating concentrations of EF-Tu-GTP-Phe-tRNA ${ }^{\text {Phe }}$ ternary complex (TC-Phe) (Fig. 3A). The extent of dipeptide formation was lower on $\Delta \mathrm{L} 27$ ribosomes $(40 \%)$ compared with wt ribosomes $(60 \%)$, as previously observed (Wower et al. 1998). However, the rate was very similar to the wt control (90 sec-1 and $110 \mathrm{sec}^{-1}$ for $\Delta \mathrm{L} 27$ and wt, respectively). To investigate the origin of this small difference, we also measured the rate of dipeptide formation on ribosomes carrying an N-terminal truncated version of L27 (L27 $\Delta 1-6)$. The dipeptide rate obtained with these ribosomes, $90 \mathrm{sec}^{-1}$, indicates that the small difference is due solely to the presence of the first six residues of L27 (Fig. 3A).

Apart from the proposed direct participation in the PT mechanism, the L27 tail might be involved in cognate
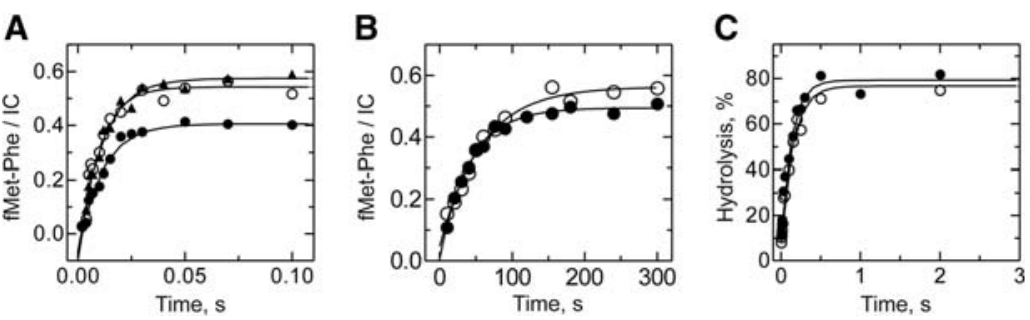

FIGURE 3. Reactions with natural substrates. (A) PT with cognate aa-tRNA was measured upon mixing wt (open circles), L27 $\Delta 1-6$ (closed triangles), or $\Delta$ L27 (closed circles) ICs (50 nM) containing fMet-tRNA ${ }^{\mathrm{fMet}}$ in the P site and a UUC codon in the A site with TC-Phe $(10 \mu \mathrm{M})$. Solid lines represent the results of exponential fitting of the time points, which yielded the rates of $110 \pm$ $13,90 \pm 9$, and $90 \pm 8 \mathrm{sec}^{-1}$ for wt, L27 $\Delta 1-6$, and $\Delta \mathrm{L} 27$ ribosomes, respectively. (B) PT with near cognate aa-tRNA was measured as in $A$, using ICs with a CUC codon in the A site. Exponential fitting (solid lines) yielded the rates of $0.017 \pm 0.002$ and $0.024 \pm 0.002 \mathrm{sec}^{-1}$ for wt and $\Delta \mathrm{L} 27$ ribosomes, respectively. $(C)$ Peptide release was measured upon mixing wt (open circles) or $\Delta \mathrm{L} 27$ (closed circles) ICs $(75 \mathrm{nM})$ programmed on a UAA codon with RF2 $(1.5 \mu \mathrm{M})$. The rates, determined by exponential fitting (solid lines), were $6.6 \pm 0.6$ and $7.6 \pm 0.8 \mathrm{sec}^{-1}$ for wt and $\Delta \mathrm{L} 27$ ri- 
aa-tRNA selection. In fact, the crystal structure of the T. thermophilus ribosome in complex with a near-cognate ternary complex shows the N-terminal tail of L27 in a different conformation as compared to the cognate tRNA (Jenner et al. 2010). We reasoned that if $\mathrm{L} 27$ is involved in tRNA selection, PT to a near-cognate aa-tRNA would be affected by the absence of L27. To test this hyphothesis, we reacted ribosomes carrying $\mathrm{fMet}^{\mathrm{tRNA}} \mathrm{fMet}^{\mathrm{fin}}$ the $\mathrm{P}$ site and a CUC codon in the A site (coding for leucine) with an excess of the near cognate Phe-tRNA ${ }^{\text {Phe }}$-EF-Tu-GTP (Fig. 3B). In this case, the extent and the rate of the PT reaction were essentially identical (rates of 0.014 and $0.019 \mathrm{sec}^{-1}$ for wt and $\Delta \mathrm{L} 27$ ribosomes, respectively). In summary, our data argue against any significant involvement of L27 in the mechanism of peptide-bond formation.

In addition to the PT reaction, the PTC catalyzes the hydrolysis of the peptidyl tRNA during translation termination. This prompted us to measure the impact of $\mathrm{L} 27$ in this reaction. We prepared pre-termination complexes with fMet-tRNA ${ }^{\text {fMet }}$ in the $\mathrm{P}$ site and a UAA stop codon in the A site and followed the kinetics of peptide release in the presence of saturating concentrations of RF2. Also in this case, no difference was observed between the wt and $\Delta \mathrm{L} 27$ ribosomes (Fig. $3 \mathrm{C}$ ). The rate of peptide release $\left(\sim 7 \mathrm{sec}^{-1}\right)$ was in agreement with that previously determined using wt (MRE600) ribosomes (Kuhlenkoetter et al. 2011; Indrisiunaite et al. 2015).

To investigate the importance of L27 for the steps of the elongation cycle that are not reflected in our model assays (e.g., translocation, tRNA competition) or for context-dependent effects on peptide-bond formation, we translated a full-length natural mRNA with $\Delta \mathrm{L} 27$ ribosomes, using the mRNA coding for the E. coli CspA as a model (Rudorf et al. 2014). The time courses of translation (Fig. 4A) show that the mutant ribosomes translate the mRNA as efficiently as the wt ribosomes and without significant pausing, confirming that deletion of L27 does not have adverse effects on incorporation of amino acids other than Phe that was tested above. The average elongation rate per codon, as determined by fitting of the intensity change of the full-length product, was $1.3 \mathrm{aa} \mathrm{sec}^{-1}$ for the wt and $0.8 \mathrm{aa} \mathrm{sec}^{-1}$ for the $\Delta$ L27 ribosomes (Fig. $4 \mathrm{~B}$ ).

Taken together, our data strongly argue against an important contribution of L27 to the core mechanism of peptide- bond formation or peptidyl-tRNA hydrolysis at the PTC. Previously reported phenotypes of the mutant ribosomes can, in our opinion, be explained by the fact that the absence of L27 impairs the 50S subunit assembly and subunit association, thereby yielding a nonhomogeneous population of active and inactive ribosomes inside the cell. Indeed, the major phenotype we observed is an impaired $70 \mathrm{~S}$ ribosome formation, which could explain the growth phenotype and the low yield of translation initiation. One small additional effect may be related to the stabilization of the substrates on the ribosome by the N-terminal tail of L27, as suggested by the subtle kinetic effects of L27 on fMetPhe formation and overall translation.

There are currently two main suggestions for the mechanism of ribosomal peptide-bond formation, the so-called proton shuttle (Trobro and Åqvist 2005) and the proton wire (Polikanov et al. 2014) models. Both models are consistent with the experimental data available so far, including the $\mathrm{pH} /$ rate profiles for different substrates, mutational analysis, and KIE and KSIE measurements (Katunin et al. 2002; Youngman et al. 2004; Beringer and Rodnina 2007; Lang et al. 2008; Wohlgemuth et al. 2008; Hiller et al. 2011; Kuhlenkoetter et al. 2011; Zaher et al. 2011). Both models suggest that the proton from the attacking amine is transferred to the leaving group through the $2^{\prime}$-OH of the P-site tRNA A76; however, the impact of L27 and the exact path of proton transfer is different (we note that at a time when the proton shuttle model was suggested, the positions of the water molecules in the catalytic site were not known with precision). Although L27 does not play a role in the proton shuttle model, the wire model (Polikanov et al. 2014) suggests a contribution of the N-terminal amine of L27 in restricting the access of water molecules by closing the reaction pocket, thereby delaying the loss of a proton from a catalytic water molecule to the bulk solvent. The wire model would predict that the absence of the $\mathrm{N}$ terminus of L27 should alter both the rates of intermediate formation and the conversion of the intermediate into products, which is clearly not consistent with the present experiments. However, we cannot exclude that in the absence of L27, some other group (protein, rRNA, or water) takes over the functions of L27 (e.g., closes the reaction pocket). Alternatively, it is also possible that although the wire model is correct as to the path for proton transfer, L27 does not play the proposed
A

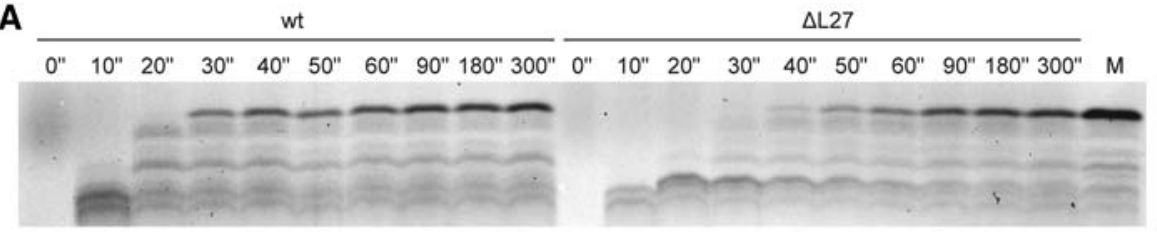

B

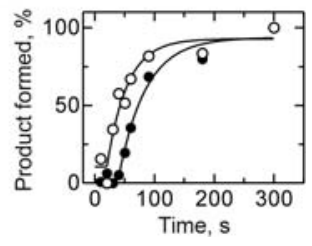

FIGURE 4. Single-round translation of CspA mRNA. (A) Time courses of in vitro translation using wt and $\Delta$ L27 ribosomes. (M) Marker, translation product obtained with wt MRE600 ribosomes. $(B)$ Kinetics of the translation by wt (open circles) and $\Delta \mathrm{L} 27$ (closed circles) ribosomes, as obtained by densitometry of the full-length CspA bands shown in $A$. The last point in each time course was set to $100 \%$. 
role even though it is located in the vicinity. Finally, both pathways - the shuttle and the wire-may turn out to be isoenergetic; in the absence of L27, the ribosome may favor the shuttle mechanism that does not involve L27.

\section{MATERIALS AND METHODS}

\section{Strains, chemicals, and buffers}

E. coli strains IW312 ( $\Delta \mathrm{L} 27)$ and IW312 expressing the full-length L27 (wt) or its N-terminally truncated version (L27 $\Delta 1-6)$ from the plasmid pPOT1AE were a kind gift from Robert Zimmermann (University of Massachusetts Amherst) (Maguire et al. 2005). Chemicals were from Roche Molecular Biochemicals, SigmaAldrich, or Merck. Radioactive compounds were from Hartmann Analytic. MNV mRNA (5'-GGCAAGGAGGUAAAUAAUGNNN$A C G A U U-3^{\prime}$, in which the coding sequence is in italics and the A-site codon (underlined) is NNN (UUC coding for Phe, CUC coding for Leu, CCG coding for Pro, and UAA as the stop codon), was purchased from IBA. Buffer A: $50 \mathrm{mM}$ Tris-HCl, pH 7.5, $70 \mathrm{mM}$ $\mathrm{NH}_{4} \mathrm{Cl}, 30 \mathrm{mM} \mathrm{KCl}$, and $7 \mathrm{mM} \mathrm{MgCl}_{2}$. Buffer B (HiFi): $50 \mathrm{mM}$ Tris-HCl, pH 7.5, $70 \mathrm{mM} \mathrm{NH} 4 \mathrm{Cl}, 30 \mathrm{mM} \mathrm{KCl}, 3.5 \mathrm{mM} \mathrm{MgCl}$, $0.5 \mathrm{mM}$ spermidine, $8 \mathrm{mM}$ putrescine, and $2 \mathrm{mM}$ DTT. The $\mathrm{pH}$ of buffers and Pmn stocks was adjusted to $6.5,7.5$, or 8.5 at $37^{\circ} \mathrm{C}$.

\section{Ribosomes, initiation, and ternary complexes}

For ribosome preparation, cells were grown in LB medium supplied with $50 \mu \mathrm{g} / \mathrm{mL}$ kanamycin, $1 \mathrm{mM}$ ITPG, and, where appropriate, $50 \mu \mathrm{g} / \mathrm{mL}$ ampicillin, as described in Maguire et al. (2005). Ribosomes, initiation factors, EF-Tu, EF-G, tRNAs, and RF2 were prepared as previously described (Rodnina et al. 1995; Gromadski and Rodnina 2004; Kuhlenkoetter et al. 2011). Ternary complex EF-Tu-GTP-Phe-tRNA ${ }^{\text {Phe }}$ was prepared by incubating EF-Tu (40 $\mu \mathrm{M})$, GTP $(1 \mathrm{mM})$, phosphoenol pyruvate $(3 \mathrm{mM})$, pyruvate kinase $(0.05 \mathrm{mg} / \mathrm{mL})$, and $\left[{ }^{14} \mathrm{C}\right]$ Phe-tRNA ${ }^{\text {Phe }}$ or $\left[{ }^{14} \mathrm{C}\right]$ Pro-tRNA ${ }^{\text {Pro }}(20$ $\mu \mathrm{M}$ ) in buffer A. Initiation complexes (ICs) were prepared by incubating ribosomes $(1 \mu \mathrm{M})$ with mRNA $(3 \mu \mathrm{M})$, initiation factors $(1.5$ $\mu \mathrm{M}$ each $), \mathrm{f}\left[{ }^{3} \mathrm{H}\right] \mathrm{Met}^{-\mathrm{tRNA}}{ }^{\mathrm{fMet}}(2 \mu \mathrm{M})$, and GTP $(1 \mathrm{mM})$ in buffer A for $30 \mathrm{~min}$ at $37^{\circ} \mathrm{C}$. Post-translocation complexes carrying fMetPhe-tRNA $^{\text {Phe }}$ or fMetPro-tRNA ${ }^{\text {Pro }}$ in the P site were formed by reacting ICs with a twofold excess of the suitable TC and catalytic amounts of EF-G for $5 \mathrm{~min}$ at $37^{\circ} \mathrm{C}$. Ribosome complexes were purified by centrifugation through sucrose cushions (1.1 M sucrose in buffer A) at 259,000 $\mathrm{g}$ for $2 \mathrm{~h}$. Pellets were dissolved in buffer A and stored at $-80^{\circ} \mathrm{C}$ in small aliquots.

\section{Western blot}

Twenty-five picomoles of MRE600, wt or $\triangle \mathrm{L} 2770 \mathrm{~S}$ ribosomes were digested for $1 \mathrm{~h}$ at $37^{\circ} \mathrm{C}$ with $0.1 \mu \mathrm{g} / \mu \mathrm{L}$ Benzonase RNase (SigmaAldrich) before loading on an 18\% acrylamide SDS-PAGE gel. The presence of L27 was determined with the use of polyclonal antibodies against L27.

\section{Mass spectrometry}

One hundred picomoles of wt and $\Delta \mathrm{L} 27$ ribosomes were proteolyzed with trypsin and analyzed by LC-ESI MS/MS as described
(Davydov et al. 2013). Thermo RAW files were processed with MaxQuant (1.5.2.8) against a Uniprot E. coli (K12) database. 50S subunit proteins were quantified by intensity-based label-free quantification using MaxQuant Label Free Quantification (LFQ) values (Cox et al. 2014).

\section{Kinetics experiments}

All experiments were carried out at $37^{\circ} \mathrm{C}$, if not stated otherwise. The formation of $\mathrm{f}\left[{ }^{3} \mathrm{H}\right] \mathrm{Met}-\mathrm{Pmn}$ and of $\mathrm{f}\left[{ }^{3} \mathrm{H}\right] \mathrm{Met}\left[{ }^{14} \mathrm{C}\right] \mathrm{Phe} /$ ProPmn was measured upon rapid mixing of equal volumes $(14 \mu \mathrm{L})$ of ICs ( $50 \mathrm{nM}$; final concentrations are reported throughout the paper) and Pmn (2.5-10 mM) in a quench-flow apparatus (RQF-3, KinTek Corporation). Samples were quenched with $25 \%$ formic acid and $\mathrm{f}\left[{ }^{3} \mathrm{H}\right]$ Met-Pmn was released upon addition of $500 \mu \mathrm{L}$ of $1.5 \mathrm{M}$ sodium acetate $(\mathrm{pH} 4.5)$ saturated with $\mathrm{MgSO}_{4}$ and extracted in $750 \mu \mathrm{L}$ ethyl acetate. Radioactivity in $500 \mu \mathrm{L}$ of the organic phase was counted. Alternatively, samples were quenched with $0.5 \mathrm{M}$ $\mathrm{KOH}$, and $\mathrm{f}\left[{ }^{3} \mathrm{H}\right] \mathrm{Met}\left[{ }^{14} \mathrm{C}\right] \mathrm{Phe} / \mathrm{Pro}-\mathrm{Pmn}$ peptides were separated by reverse-phase HPLC (see below). For reactions with aa-tRNAs, ICs $(50 \mathrm{nM})$ were mixed in the quench-flow with a large excess of the ternary complex EF-Tu-GTP-Phe-tRNA ${ }^{\text {Phe }}(10 \mu \mathrm{M})$. Samples were quenched with $0.5 \mathrm{M} \mathrm{KOH}$, hydrolyzed for $30 \mathrm{~min}$ at $37^{\circ} \mathrm{C}$, and neutralized with one-tenth volume of glacial acetic acid. Dipeptides were analyzed by HPLC according to Katunin et al. (2002). Radioactivity in the eluate was counted after addition of Lumasafe Plus scintillation cocktail (PerkinElmer). Time courses were fitted to an exponential function, $F=F_{\infty}+A \times \exp \left(-k_{\text {app }} \times\right.$ $t$ ), with a time constant, $k_{\text {app }}$, the amplitude of the signal change, $A$, the final signal, $F_{\infty}$, and the fluorescence signal at time $t, F$. For fitting of the time courses shown in Figure 2A,B, an additional exponential term was included. Calculations were performed using Prism (GraphPad software). The rates are reported \pm SEM.

\section{In vitro translation}

Single-round translation of the full-length CspA mRNA (70 aa) was performed according to Doerfel et al. (2013) and Rudorf et al. (2014). Wt and $\Delta$ L27 ICs were prepared as described above using Bodipy-FL-Met-tRNA ${ }^{\mathrm{fMet}}$. Translation was initiated by mixing IC $(20 \mathrm{nM})$ with a translation mix containing EF-Tu $(39 \mu \mathrm{M})$, total aa-tRNA $(19.3 \mu \mathrm{M})$, EF-G $(2 \mu \mathrm{M})$, GTP $(1 \mathrm{mM})$, phosphoenol pyruvate $(1.3 \mathrm{mM})$, and pyruvate kinase $(0.1 \mathrm{mg} / \mathrm{mL})$ at $37^{\circ} \mathrm{C}$ in buffer B. The translation product was separated on a $16.5 \%$ Tris-tricinePAGE (Schägger and von Jagow 1987) and visualized by the fluorescent reporter at the $\mathrm{N}$ terminus of the peptides. The intensity of the full-length product was quantified with ImageJ. Average translation rates per codon were determined by fitting with a delay phase followed an exponential function (GraphPad software).

\section{ACKNOWLEDGMENTS}

We thank Robert Zimmermann for the $\Delta$ L27 E. coli strains, Richard Brimacombe for the antibodies against L27, Henning Urlaub and the bioanalytical mass spectrometry group for the MS analysis, and O. Geintzer, S. Kappler, C. Kothe, T. Niese, A. Pfeiffer, U. Plessmann, and M. Zimmermann for expert technical assistance. 
Received July 15, 2015; accepted September 4, 2015.

\section{REFERENCES}

Armache J-P, Jarasch A, Anger AM, Villa E, Becker T, Bhushan S, Jossinet F, Habeck M, Dindar G, Franckenberg S, et al. 2010 Localization of eukaryote-specific ribosomal proteins in a $5.5-\AA$ cryo-EM map of the $80 \mathrm{~S}$ eukaryotic ribosome. Proc Natl Acad Sci 107: 19754-19759.

Beringer M, Rodnina MV. 2007. Importance of tRNA interactions with $23 \mathrm{~S}$ rRNA for peptide bond formation on the ribosome: studies with substrate analogs. Biol Chem 388: 687-691.

Beringer M, Bruell C, Xiong L, Pfister P, Bieling P, Katunin VI, Mankin AS, Böttger EC, Rodnina MV. 2005. Essential mechanisms in the catalysis of peptide bond formation on the ribosome. J Biol Chem 280: 36065-36072.

Brunelle JL, Youngman EM, Sharma D, Green R. 2006. The interaction between C75 of tRNA and the a loop of the ribosome stimulates peptidyl transferase activity. RNA 12: 33-39.

Cox J, Hein MY, Luber CA, Paron I, Nagaraj N, Mann M. 2014. Accurate proteome-wide label-free quantification by delayed normalization and maximal peptide ratio extraction, termed MAXLFQ. Mol Cell Proteomics 13: 2513-2526.

Davydov II, Wohlgemuth I, Artamonova II, Urlaub H, Tonevitsky AG, Rodnina MV. 2013. Evolution of the protein stoichiometry in the L12 stalk of bacterial and organellar ribosomes. Nat Commun 4: 1387.

Doerfel LK, Wohlgemuth I, Kothe C, Peske F, Urlaub H, Rodnina MV. 2013. EF-P is essential for rapid synthesis of proteins containing consecutive proline residues. Science 339: 85-88.

Gromadski KB, Rodnina MV. 2004. Kinetic determinants of high-fidelity tRNA discrimination on the ribosome. Mol Cell 13: 191-200.

Hiller DA, Singh V, Zhong M, Strobel SA. 2011. A two-step chemical mechanism for ribosome-catalysed peptide bond formation. Nature 476: 236-239.

Hofer A, Bussiere C, Johnson AW. 2007. Mutational analysis of the ribosomal protein rpL10 from yeast. J Biol Chem 282: 32630-32639.

Indrisiunaite G, Pavlov MY, Heurgué-Hamard V, Ehrenberg M. 2015. On the $\mathrm{pH}$ dependence of class-1 RF-dependent termination of mRNA translation. J Mol Biol 427: 1848-1860.

Jenner L, Demeshkina N, Yusupova G, Yusupov M. 2010. Structural rearrangements of the ribosome at the tRNA proofreading step. Nat Struct Mol Biol 17: 1072-1078.

Johansson M, Ieong K-W, Trobro S, Strazewski P, Aqvist J, Pavlov MY, Ehrenberg M. 2011. pH-sensitivity of the ribosomal peptidyl transfer reaction dependent on the identity of the A-site aminoacyl-tRNA. Proc Natl Acad Sci 108: 79-84.

Katunin VI, Muth GW, Strobel SA, Wintermeyer W, Rodnina MV. 2002. Important contribution to catalysis of peptide bond formation by a single ionizing group within the ribosome. Mol Cell 10: 339-346.

Kuhlenkoetter S, Wintermeyer W, Rodnina MV. 2011. Different substrate-dependent transition states in the active site of the ribosome. Nature 476: 351-354.

Lang K, Erlacher M, Wilson DN, Micura R, Polacek N. 2008. The role of $23 \mathrm{~S}$ ribosomal RNA residue A2451 in peptide bond synthesis revealed by atomic mutagenesis. Chem Biol 15: 485-492.

Maguire BA, Beniaminov AD, Ramu H, Mankin AS, Zimmermann RA. 2005. A protein component at the heart of an RNA machine: The importance of protein $\mathrm{L} 27$ for the function of the bacterial ribosome. Mol Cell 20: 427-435.

Okuda K, Seila AC, Strobel SA. 2005. Uncovering the enzymatic pKa of the ribosomal peptidyl transferase reaction utilizing a fluorinated puromycin derivative. Biochemistry 44: 6675-6684.

Pape T, Wintermeyer W, Rodnina MV. 1998. Complete kinetic mechanism of elongation factor Tu-dependent binding of aminoacyltRNA to the A site of the E. coli ribosome. EMBO J 17: 7490-7497.

Polikanov YS, Steitz TA, Innis CA. 2014. A proton wire to couple aminoacyl-tRNA accommodation and peptide-bond formation on the ribosome. Nat Struct Mol Biol 21: 787-793.

Rodnina M, Fricke R, Kuhn L, Wintermeyer W. 1995. Codon-dependent conformational change of elongation factor Tu preceding GTP hydrolysis on the ribosome. EMBO J 14: 2613-2619.

Rudorf S, Thommen M, Rodnina MV, Lipowsky R. 2014. Deducing the kinetics of protein synthesis in vivo from the transition rates measured in vitro. PLoS Comput Biol 10: e1003909.

Schägger H, von Jagow G. 1987. Tricine-sodium dodecyl sulfate-polyacrylamide gel electrophoresis for the separation of proteins in the range from 1 to $100 \mathrm{kDa}$. Anal Biochem 166: 368-379.

Selmer M, Dunham CM, Murphy FV IV, Weixlbaumer A, Petry S, Kelley AC, Weir JR, Ramakrishnan V. 2006. Structure of the 70S ribosome complexed with mRNA and tRNA. Science 313: 1935-1942.

Trobro S, Åqvist J. 2008. Role of ribosomal protein L27 in peptidyl transfer. Biochemistry 47: 4898-4906.

Ude S, Lassak J, Starosta AL, Kraxenberger T, Wilson DN, Jung K. 2013. Translation elongation factor EF-P alleviates ribosome stalling at polyproline stretches. Science 339: 82-85.

Voorhees RM, Weixlbaumer A, Loakes D, Kelley AC, Ramakrishnan V. 2009. Insights into substrate stabilization from snapshots of the peptidyl transferase center of the intact $70 \mathrm{~S}$ ribosome. Nat Struct Mol Biol 16: 528-533.

Wang Y, Xiao M. 2012. Role of the ribosomal protein L27 revealed by single-molecule FRET study. Protein Sci 21: 1696-1704.

Wohlgemuth I, Beringer M, Rodnina MV. 2006. Rapid peptide bond formation on isolated $50 \mathrm{~S}$ ribosomal subunits. EMBO Rep 7: 699-703.

Wohlgemuth I, Brenner S, Beringer M, Rodnina MV. 2008. Modulation of the rate of peptidyl transfer on the ribosome by the nature of substrates. J Biol Chem 283: 32229-32235.

Wohlgemuth I, Pohl C, Rodnina MV. 2010. Optimization of speed and accuracy of decoding in translation. EMBO J 29: 3701-3709.

Wower IK, Wower J, Zimmermann RA. 1998. Ribosomal protein L27 participates in both 50S subunit assembly and the peptidyl transferase reaction. J Biol Chem 273: 19847-19852.

Wower J, Kirillov SV, Wower IK, Guven S, Hixson SS, Zimmermann RA. 2000. Transit of tRNA through the Escherichia coli ribosome: cross linking of the $3^{\prime}$ end of tRNA to specific nucleotides of the $23 \mathrm{~S}$ ribosomal RNA at the A, P, and E sites. J Biol Chem 275: 37887-37894.

Xiao M, Wang Y. 2012. L27-tRNA interaction revealed by mutagenesis and $\mathrm{pH}$ titration. Biophys Chem 167: 8-15.

Youngman EM, Brunelle JL, Kochaniak AB, Green R. 2004. The active site of the ribosome is composed of two layers of conserved nucleotides with distinct roles in peptide bond formation and peptide release. Cell 117: 589-599.

Zaher HS, Shaw JJ, Strobel SA, Green R. 2011. The $2^{\prime} \mathrm{OH}$ group of the peptidyl-tRNA stabilizes an active conformation of the ribosomal PTC. EMBO J 6: 2445-2453. 

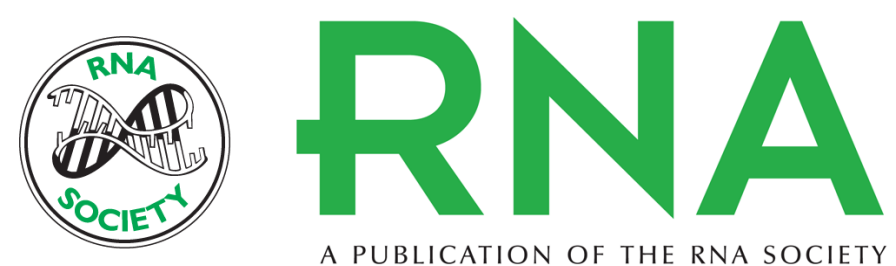

A PUBLICATION OF THE RNA SOCIETY

\section{Activities of the peptidyl transferase center of ribosomes lacking protein L27}

Cristina Maracci, Ingo Wohlgemuth and Marina V. Rodnina

RNA 2015 21: 2047-2052 originally published online October 16, 2015

Access the most recent version at doi:10.1261/rna.053330.115

References This article cites 36 articles, 15 of which can be accessed free at: http://rnajournal.cshlp.org/content/21/12/2047.full.html\#ref-list-1

Open Access Freely available online through the RNA Open Access option.

Creative This article, published in $R N A$, is available under a Creative Commons License

Commons (Attribution 4.0 International), as described at

License http://creativecommons.org/licenses/by/4.0/.

Email Alerting Receive free email alerts when new articles cite this article - sign up in the box at the Service top right corner of the article or click here.

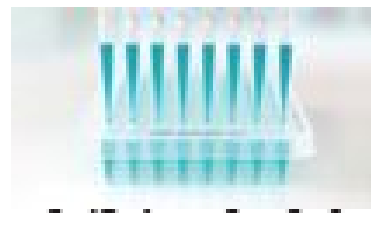

\section{Providing Precise Solutions for} your research.

To subscribe to RNA go to:

http://rnajournal.cshlp.org/subscriptions

(C) 2015 Maracci et al.; Published by Cold Spring Harbor Laboratory Press for the RNA Society 